\title{
Die samestelling en gebruik van vraelyste in kerklike opnames met verwysings na die Ned Geref Kerk se Kerkspieël-vraelyste
}

\author{
Zaaiman, Johan \\ Noord-Wes Universiteit \\ johan.zaaiman@nwu.ac.za
}

\begin{abstract}
The construction and usage of questionnaires in church surveys with references to the Dutch Reformed church's 'Kerkspieël' questionnaires

This article works from the premise that practical theology interprets the functioning of the church. Therefore, practical theologians should also be knowledgeable about empirical approaches to investigate these matters. Surveys are an important tool in empirical investigations and questionnaire construction forms an integral part of this process to ensure collection of quality information. However, questionnaire construction can be challenging since it involves human communication and interpretation that is fluid and unique by nature, but attempts to generate from it standardised and controlled responses. Therefore, the quality of each item in a questionnaire must be examined thoroughly. As an example, this article identifies certain flaws in the Dutch Reformed Church's 'Kerkspieël' surveys. These entail the following: double barrelled, ambiguous, unclear, general, abstract and emotionallyrelated wording, timeframe in questions, leading questions, and assumed knowledge. In practical theological research, these deficiencies can serve as examples urging researchers to be more focused when aiming to develop quality surveys.
\end{abstract}

Key words

Kerkspieël; church research; questionnaire; questionnaire construction; questionnaire items; questions and statements

\section{Inleiding}

Kerke gebruik gereeld opnames om inligting oor die kerk se aard te bekom. Die inligting wat uit opnames bekom word, kan nuttig in kerklike bestuursake aangewend word. Om in kerklike verband betekenisvol te 
wees, is dit belangrik dat sodanige inligting ook van gehalte sal wees. Die waarde van inligting uit opnames is afhanklik van die gehalte van die opnameproses. Aangesien opnames in praktiese teologie ingespan word, is dit belangrik om te besin oor die aspekte wat tot 'n gehalte-opname kan bydra.

Hierdie artikel ontleed voorbeelde uit die Nederduitse Gereformeerde Kerk (Ned.Geref. Kerk) se Kerkspieël-opnames om aan te dui dat die samestelling van vraelyste 'n uiters belangrike onderdeel uitmaak van die proses wat die gehalte beheer van inligting wat ingesamel word. Daarom moet hierdie vraelyssamestelling spesiale aandag geniet wanneer opnames ontwerp word. Daar kom dikwels gevalle in kerklike opnames voor, soos ook in die Kerkspieël-voorbeelde, waar nie genoegsaam aandag aan vraelyste gegee word nie. Hierdie artikel lig probleme uit wat navorsers kan voorkom wanneer hulle vraelyste saamstel. Sodoende wil die artikel 'n bydrae lewer om praktiese teologie sterker bewus te maak van die uitdagings om 'n vraelys as 'n toepaslike, betroubare en geldige meetinstrument daar te stel.

Tereg kan gevra word of 'n besinning oor die gehalte van opnames, en spesifiek oor gehaltebeheer in die samestelling van vraelyste, 'n plek in praktiese teologie het. Die uitgangspunt van hierdie artikel is dat praktiese teologie navorsing in die praktyk doen. Gevolglik sluit dit nadenke in oor empiriese aspekte van navorsing. Sodanige empiriese nadenke staan teenoor idealistiese konstrukte van die geloof. 'n Empiriese benadering wil bydra tot 'n verantwoordelike uitleef van die geloof. 'n Bekende uitspraak van die hervormer, Martin Luther, is: Experientia fait theologum ("ondervinding maak die teoloog"). Praktiese teologie se doel is om die geloofslewe met mense se ondervindings te verbind. Gevolglik is hierdie veld van teologie se empiriese belangstelling betekenisvol (Heimbrock 2011:156).

Praktiese teologie beweeg tussen die Christelike teks en algemeen menslike ondervinding. Daarom word die taal van praktiese teologie gekenmerk deur 'n vorm van wisselwerking tussen hierdie twee aspekte waarin albei belangrik is. Hierteenoor het Paul Tillich en Karl Barth in die middel van die $20^{\text {ste }}$ eeu eerder 'n wisselwerking tussen teologie en filosofiese en ontologiese denke beklemtoon. Tillich beskou byvoorbeeld nie empiriese ondersoek as eie aan teologie nie, maar eerder as die resultaat van metodologiese imperialisme binne teologie (Heimbrock 2011:158). Aan die ander kant onderskei Friedrich Schleiermacher in sy ensiklopedie 
tussen praktiese, filosofiese en historiese teologie. Hy beskou dit die taak van praktiese teologie om wetenskaplik oor die praktyk van die kerk na te dink (Heitink 1999:23; Nipkow 1993:51). Jean-Jacques Rosseau het ook so 'n onderskeid getref tussen die godsdienste van die priesters, die staat en die mense. Hiervolgens vereis elkeen van hierdie rolspelers 'n eie navorsingsfokus (Nipkow 1993:53). Die nadenke wat praktiese teologie se model van wisselwerking dra, het dus diep wortels.

Teenoor hierdie interne beskouings het teologie in die laaste dekades 'n meer interdissiplinêre aard ontwikkel (Dreyer 2012:36; Miller-McLemore 2012:3). Hierin het die fenomenologiese filosofie 'n belangrike rol gespeel deur die beklemtoning van menslike lewenservaring wat in die konkrete werklikheid ingebed is. Die menslike liggaam se vermoëns stel individue in staat om ander mense te beleef en van 'n lewensomgewing bewus te wees. Hierdie omvattende belewing van die werklikheid geskied in die ervarings van elke dag (Pieterse 1994:78; Heimbrock 2011:161). Mense se daaglikse belewing is dus geskoei op die ervarings wat hulle beleef en kan interpreteer. Dit gaan dus oor hoe hulle uitdrukking gee aan en hulle kulturele vermoëns om daardie geïnterpreteerde ervarings te vertolk (Heimbrock 2011:163).

Ook godsdienstige belewenisse is afgestem op hierdie konkrete werklikheid en kan dus empiries bestudeer word (Heimbrock 2011:167). Hierdie empiriese hoek het in die protestantse teologie veral in die laaste helfte van die $20^{\text {ste }}$ eeu sterk na vore getree en 'n heersende posisie begin inneem (Nipkow 1993:52). Dié tendens is ook aangehelp as reaksie op sekularisasie in die Westerse wêreld. Die verweer was om deur empiriese ondersoek 'n antwoord te vind vir die negatiewe tendense waaraan die kerk blootgestel is (Nipkow 1993:53).

\section{Probleemstelling: nuwe uitdagings vir praktiese teologie}

In die lig van die bogenoemde ontwikkeling bied praktiese teologie tans 'n belangrike interpretasie van die kerk se funksionering. Sodoende raak hierdie veld van teologie 'n belangrike deelnemer in die dialoog tussen kerk en teologie (Nipkow 1993:50; Fuchs 2001:9). Dit gaan nie net daaroor om die kerk aan teologiese uitsprake te toets nie, maar ook om daardie uitsprake se empiriese toepaslikheid te beoordeel. Waar bevind word dat uitsprake ontoepaslik is, het praktiese teologie die uitdaging om die empiriese voorwaardes vir toepaslikheid vas te stel. Dit gebeur deur die 
"behoort" en die "werklikheid" teenoor mekaar op te weeg (Fuchs 2001:9). Tog geskied hierdie proses met die verstandhouding dat uitsprake oor die teologie en die werklikheid nie noodwendig teenoor mekaar gestel kan word nie, en in heelwat gevalle vervleg is (Fuchs 2001:12). Voorts behoort, kan, moet navorsingsvrae beantwoord word oor die aard, werking en veld van geloof, diakonie en kerkwees (Fuchs 2001:16-17; Pieterse 1994:82; Van der Ven 1993:77). Dit is dus belangrik dat teoloë ook insig het in empiriese benaderings om toepaslike en praktiserende teoloë te kan wees (Osmer 2008:41). In die lig hiervan is dit duidelik dat opnames nuttig in die teologiese en kerklike verband gebruik kan word.

Hierdie kundigheid oor empiriese navorsing is verder belangrik want kerkwees word nie afgehandel nie. Dit behels 'n onaf proses waarin kerke voordurend streef om aan hulle goddelike roeping te voldoen. Kerke moet word wat hulle in Christus bestem is om te wees (Nel \& Schoeman 2015:86-87). Dit is hierdie soekende en geleefde identiteit van 'n kerk wat oor 'n empiriese gestalte beskik binne 'n konteks en tyd (Nel \& Schoeman 2015:87). Deur hierdie gestalte van die kerk te ondersoek, kan hierdie instelling in identiteitswording bemagtig en versterk word. Empiriese metodologie is daarom nuttig om in sodanige kerklike ontleding te gebruik. Dit kan bydra tot die proses waarin kerke hulle eie bestaansdoel ondersoek binne 'n globale omgewing wat gekenmerk is deur netwerke, tegnologiese ontwikkeling en sosio-politieke veranderings (Nel \& Schoeman 2015:96). Aangesien kerke kontekstueel funksioneer, help opnames die navorsers om die verloop van hierdie werking en verandering te evalueer (Schoeman 2015:60).

In die lig van hierdie kerklike behoefte aan inligting het die Ned. Geref. Kerk by die Algemene Sinode van 1978 'n kerklike sensus versoek. Die eerste sensus het in 1981 geskied onder leiding van prof. IJ van Eeden. Dit is opgevolg deur 'n tweede sensus in 1985 (Schoeman 2011:474). Ná Van Eeden se dood is die opnames voortgesit met navorsingspanne waarvan die lede gewissel het. Verdere opnames het plaasgevind in 1989, 1993, 1996, 2000, 2004, 2006, 2010 en 2014. Die fokus in hierdie ondersoeke het mettertyd weggeskuif vanaf bloot sosio-demografiese opnames na meerdoelige kerklike opnames waarin gepoog is om verskillende aspekte van kerkwees te peil. 
Die doelstellings van hierdie toetse oor kerkwees het in die opvolgende opnames ingrypend verander. Die vraelyste is vir verskillende teikengroepe ontwikkel en van die vrae daarin het voortdurend verander (Schoeman 2011:476-477, Zaaiman 2011:656). Die groot verskuiwing in die ondersoek se doelwitte was vanaf beskrywende na ondersoekende navorsing (Zaaiman 2011:680). Hierdie klemverskuiwing het veral verband gehou met ontwikkelings in die kerk. Die kerk is al meer blootgestel aan diverse behoeftes van lidmate asook veranderde sosiaal, politieke en ekonomiese omstandighede. Gevolglik was die kerkleiers onseker oor maniere om hulle in hierdie werklikheid te posisioneer. Die behoefte aan inligting is dus as dringend beskou om die kerk te help met besluitneming in 'n veranderende omgewing.

Die Kerkspië̈l-opnames het, wat navorsing betref, egter voor ernstige uitdagings te staan gekom. Dit het deurgaans van steekproefneming gebruik gemaak en aanvanklik'n hoë responskoers gehad (Schoeman 2011:477-479). Zaaiman (2011:648-649) toon breedvoerig aan hoe die steekproefproses in die Kerkspieëls mettertyd verswak het en dat "die navorsers nie die formule of die (steekproef)proses begryp het nie en onverskillig daarteenoor gestaan het". Hierdie gebreke in die steekproefproses en die verminderde responskoers oor die Kerkspieël-opnames heen, het die waarde van hierdie opnames en die geldigheid van die inligting wat daardeur verkry is, aansienlik beperk. Benewens die leemtes in die steekproefneming het Zaaiman (2011) en Zaaiman \& Rautenbach (2011) ook leemtes uitgewys in die probleemstelling, administrasie van die responskoers, geldigheid en betroubaarheid van die opnames.

Soos gemeld, is verskeie gebreke in die Kerkspieël-opnames reeds uitgewys, veral wat die beplanning, strukturering en uitvoering betref. Nogtans is die gehalte van die vraelyste se items as sodanig tot op datum nie beoordeel nie. Hierdie artikel lewer nie spesifiek daartoe 'n bydrae nie, maar gebruik die vraelyste se items as voorbeelde van gevalle waar leemtes algemeen in vraelyste kan voorkom. Daardeur wil aangetoon word hoe belangrik dit is dat die vraelyste in opnames aan hoogstaande navorsingstandaarde moet voldoen om die geldigheid en betroubaarheid van so 'n opname bo verdenking te stel en te verseker dat die inligting wat ingesamel is van 'n hoë gehalte is. Daarom moet hierdie vraelyssamestelling spesiale aandag geniet wanneer opnames ontwerp word. 


\section{Samestelling van vraelyste}

Die samestelling van vraelyste moet spesiale aandag in die bestuur van opnamesgenietomdat vraelyste'nkernaspekbehelsvan inligtinginsameling. Die gehalte van hierdie proses is grootliks afhanklik van die gehalte van die vraelyste en die onderdele daarvan. Behoorlike samestelling van vraelyste is kernbelangrik in opnames. Daarby is dit nie 'n eenvoudige proses nie. Die rede is dat vraelyste poog om menslike kommunikasie te standaardiseer wat uiteraard uniek en nie eenvormig is nie. Teenoor hierdie dinamiese menslike kreatiwiteit staan die opstel van 'n vraelys waarin navorsers die inligtinginsameling so eenvoudig en eenduidig moontlik probeer maak. In hierdie afdeling word die probleem oorsigtelik behandel as agtergrond vir die beoordeling van items uit vraelyste binne Kerkspieël-opnames.

Gevorderde literatuur oor opnames skeep dikwels aanwysings af oor die saamstel van vraelyste. Sodanige literatuur beklemtoon eerder statistiese metodes om die data te verifieer en te ontleed. Sodoende onderbeklemtoon dit die belangrikheid van itemontwikkeling in vraelyste. Hierdie vorm van ontwikkeling behels 'n proses waarin konsepte uitgeklaar en geoperasionaliseer, en metingsfoute só verminder word (Tucker, Viswanathan, et al. 2010:2, 314). Om vraelysitems te ontwikkel moet die samestellers duidelik weet wat hulle konseptueel bestudeer en hoe hulle dit kan benader (Das \& Laumann 2010:10). Die hele proses moet daarop gerig wees om helderheid en sekerheid oor die betekenis van konsepte en paslike metings daarvan te kry. Dit behels 'n uitdaging omdat respondente aan vraelysitems hulle eie interpretasie kan heg wat van die navorser se bedoeling verskil. Daarom is die samestelling van vraelyste daarop gerig om betekenisse te standaardiseer en om respondente se onafhanklike en unieke betekenisgewing en interpretasie te beperk (Schwarz 2010:43).

Die vasstel van vraelysitems volg 'n moeisame proses waarin konsepte gevorm en gespesifiseer word. Metings word ontwerp, die betroubaarheid van die items beoordeel asook die geldigheid daarvan getoets. Dit verg 'n volgehoue gerigtheid op noukeurigheid wanneer die konsepte gemeet word. Daar is nie 'n universele metode waarvolgens konsepte gemeet kan word nie, want vraelyste is kontekstueel. Hier geld die tipiese kontekstuele vrae soos: Wat?, Wie?, Wanneer?, Hoekom?, Waar? en Hoe? (Oppenheim 1968:52). Elke item in 'n vraelys is daarom gebonde aan plek en tyd en 
moet omskryf word om binne 'n spesifieke konteks gestandaardiseer of geoperasionaliseer te word.

Die uitdaging is nog groter indien die konsep wat gemeet word abstrak is. Dit is makliker om oor metings ooreen te kom by betreklik eenvoudige, konkrete konsepte soos gewig en ouderdom. Die saak staan egter anders met die meer ingewikkelde, abstrakte konsepte oor houdings, persepsies en gelowe (Viswanathan 2010:286). Met sulke komplekse konsepte is daar vanuit die staanspoor 'n groter afstand tussen die konsep se betekenis en die indikators wat dit meet (in vraelyste as vrae of stellings verwoord). Gevolglik is die kans vir metingsfoute groter as by eenvoudige konsepte waar hierdie afstand nie so groot is nie.

Navorsers moet 'n noukeurige proses volg wanneer hulle items vir die meting van konsepte ontwikkel. Dit is aangesien die standaardisering en dus skep van eenvormige betekenisse van konsepte moeilik is. Tucker (2010:316) haal Edmund Husserl hieroor aan: "Only ideals have a rigorous identity." As voorbeeld verwys Husserl na 'n driehoek wat drie sye het. Die ideale konsep se definisie is duidelik, maar wanneer 'n driehoek uit papier geknip word, is dit nie dieselfde ding as die ideale konsep nie. Hierdie insig is belangrik wanneer 'n mens items ontwikkel waarmee abstrakte konsepte gemeet word. Die items en die situasie van die meting is ver van die oorspronklik abstrakte konsep verwyder en vertroebel dus die suiwerheid daarvan.

Dit is dus belangrik dat die konsepte wat in 'n vraelys gemeet word, duidelik omskryf en gedefinieer word. Dit moet duidelik wees wat die konsep behels of nie. Slegs deur so 'n duidelike definiëring kan die proses begin om verteenwoordigende metingsitems vir die konsep aan te wys. Dit vereis dat elke item behoorlik gestandaardiseer en selfduidend is en regstreeks verband hou met die konsep wat gemeet word (Viswanathan 2010:286287). Ingewikkelde konsepte se betekenis kan egter eers in verskillende betekenisdimensies opgedeel word. Vir elke dimensie moet dan paslike items vir metings geïdentifiseer word. Die konsep "liefde" kan byvoorbeeld verdeel word in 'n gevoels- en 'n handelingsdimensie.

Standaardisering is daarop gerig om by respondente dieselfde reaksie op die betekenis van die items te ontlok. Tog bly so 'n eenvormige reaksie om verskeie redes moeilik. Dit kan wees dat respondente weens verskeie 
redes nie die vrae dieselfde vertolk nie (Viswanathan 2010:287). Hier kan die probleme wydlopend wees: taal- of dialekverskille, gemoedsverskille, vergissings, gedagtedwaling, onduidelike bewoording, antwoordpatrone, leidende vrae en bevooroordeelde vrae.

Navorsers oordeel soms dat die probleem van standaardisering oorkom kan word deur gevestigde meetinstrumente/vraelyste te gebruik. Die probleem is egter dat vraelyste gewoonlik nie 'n teoretiese fundering het nie. So 'n fundering moet aandui watter konsepte die vraelys meet en hoe dit geoperasionaliseer is. Een van die verdere belangrike metodes om die betroubaarheid van metingsitems te bepaal, is om 'n loodstudie te onderneem. Deur die vraelys te administreer aan respondente soortgelyk aan dié waarvoor dit bestem is, kan die terugvoer help om af te lei of respondente die items korrek en gestandaardiseer vertolk het, of nie.

Ten diepste is die saamstel van vraelyste daarop gemik om paslike antwoorde by respondente te ontlok. Dit is daarom belangrik dat navorsers die proses van respondering verstaan. Vir 'n respons moet 'n respondent 'n antwoord bedink. Dit veronderstel dat die respondent die vraag korrek interpreteer, en oor die feite, kennis en houding beskik vir'n paslike respons. Dit kan nie as vanselfsprekend aanvaar word dat 'n respondent helder en duidelike inligting of houdings het wat op die vraag van toepassing kan wees nie. Daarby moet 'n respondent 'n respons tot bewussyn bring om te kan reageer. Só 'n proses hou met verskeie aspekte verband: plek, tyd, selfbegrip, aanvoeling, vermoë om geheue in te span, om konsepte te vorm en dit toepaslik te maak.

'n Respons is 'n produk van innerlike prosesse wat deur verskeie faktore beïnvloed word. Hier geld byvoorbeeld interpretasies oor hoe om die navorser of verteenwoordiger tevrede te stel en die respondente se gewilligheid om billik teenoor hulleself en ander te wees. Uiteindelik is 'n spesifieke respons die gevolg van 'n warboel bewustelike en onbewustelike prosesse wat lei tot 'n reaksie binne'n interaksieproses tussen respondent en navorser, of verteenwoordiger (Oppenheim 1968:49-50). Daarby moet die respondent ook daardie respons kommunikeer. Hy/sy moet oor die vermoë beskik om paslik te kommunikeer. Daarvoor moet die respondent sy/haar rol binne die interaksie aanvaar asook gemotiveer en bereid wees om die respons aan te bied (Schwarz 2010:44-45). Die mens is dus nie soos 'n soort skaal waarop temperatuur akkuraat afgelees kan word nie. Om 'n akkurate 
en paslike respons by ' $n$ individu te verkry, is dit uiters belangrik dat die vraag die respondent sal prikkel om wel paslik en akkuraat te antwoord. Daarom is die opstel van 'n vraelys so 'n moeisame proses.

Navorsers veronderstel gewoonlik dat respondente vrae in isolasie sal beoordeel en dat buitefaktore nie hulle response sal beïnvloed nie. Wanneer respondente vrae en stellings in vraelyste interpreteer, het hulle geen rede om te dink dat gewone gespreksgebruike nie ook vir dié vrae geld nie. Tipies van gesprekke is dat sake wat vooraf genoem is, die huidige gang van die gesprek kan raak. Respondente reageer dus op vrae binne die konteks waarin dit gevra word. In 'n vraelys vorm die ander vrae of stellings die konteks. 'n Respondent beoordeel dus nie vrae in isolasie nie. Daarby veronderstel respondente in die lig van gespreksgebruike dat die vrae inderdaad sal verwys na kwessies wat hulle raak. Indien die respondente nie regtig van die kwessies bewus is nie, sal hulle waarskynlik response binne die konteks van die vraelys skep (Schwarz 2010:47), of kan 'n weerstand teenoor die vraelys se "gesprekvoering" ontwikkel.

Voorts moet in ag geneem word dat respondente steeds binne die konteks van die vraelys hou. Eie menings word in 'n beperkte mate by oop vrae aangebied, maar meer in geslote vrae. Waar geslote vrae nie die respondente se mening weerspieël nie, is hulle maar min geneig om hulle eie mening in die kategorie "ander" in te voeg (Schwarz 2010:48). Dit is 'n vraag of die meting van mense se beskouings betekenisvol is buite die konteks waarin dit bestaan. Daar kan geredeneer word dat sosiale verskynsels volgens aard wisselvallig en ingewikkeld is. Gevolglik word die meting daarvan nie as so betekenisvol beskou nie (Hammersley 2010:410). In die lig hiervan is dit belangrik om die beperkings van sosiale navorsing te erken en buitensporige kennisuitsprake oor bevindings se betekenisvolheid te vermy. Dit is ook belangrik dat die metodologiese probleme en beperkings van navorsingsmetodologie in praktiese teologie erken word. Daar moet voortdurend gestreef word om prosesse te volg wat die gehalte van kennisuitsprake kan ondersteun (Hammersley 2010:421).

Ten slotte is dit dus duidelik dat vrae in 'n vraelys kommunikasie wil ontlok. As hierdie interaksie nie geskoei is op helder definisies en die deeglike operasionalisering daarvan nie, misluk dit. Die kommunikasie in vraelyste is nie soos om 'n vrag (response) op 'n skip (datastel) te laai met elke krat gemerk en geadresseer nie. In werklikheid is vraelyste 
soos visvang, waar elke vraag 'n hoek met aas is wat op 'n sekere diepte geplaas word met die hoop dat spesifieke visse (paslike response) gevang sal word (Oppenheim 1968:49). Die insamel van inligting deur vraelyste behels dus nie 'n eenvoudige funksie van versamel en oplaai nie, maar 'n kommunikasiekuns om paslike en betroubare inligting by mense uit te vis.

\section{Evaluering van vraelyste}

Uit die bespreking hier bo is dit duidelik dat dit vir praktiese teologie noodsaaklik is om behoorlike vraelyste saam te stel. Dit geld dus ook vir die Ned. Geref. Kerk se Kerkspieël-opnames om vir die kerk 'n betroubare inligtingsbron te wees. In hierdie afdeling word items van sodanige opnames as voorbeelde gebruik om knelpunte in die saamstel van vraelyste uit te wys. Om 'n vraelys as paslike, betroubare en geldige meetinstrument te ontwikkel behels 'n moeisame proses waarin die basiese beginsels van vraelyssamestelling maklik oorgesien kan word.

Wanneer vraelyste se items beoordeel word, kom die volgende kwessies dikwels ter sprake: dubbelloopbewoording, dubbelsinnigheid, onduidelike, algemene, lang, emosionele, leidende en abstrakte bewoording, onduidelike tydsraamwerke en onpaslike, te omvangryke, uitsluitende en onvolledige metingskategorieë en skale (Babbie 2007:245-251; Bryman 2016:203209; De Vos, AS et al. 2011:191-192). Vervolgens word vrae en items uit die Kerkspieëls se vraelyste gebruik as voorbeelde om enkele van hierdie kwessies te belig.

Soos reeds gemeld, is die meting van ingewikkelde konsepte eers later by Kerkspieël-opnames ingesluit. Voorbeelde van die eerste Kerkspieëls is dus nie by hierdie artikel ingesluit nie. Die voorbeelde wat wel gebruik word, kom uit die opnames van 1996-2014. In die algemeen was die Kerkspieëlvraelyste van 'n goeie gehalte. Hierdie artikel wil nie die indruk skep dat die vraelyste deurgaans gebrekkig was nie. Dit wys bloot voorbeelde uit waar leemtes wel voorkom.

'n Groot leemte wat by die Kerkspieël-opnames uitgewys kan word, is dat daar nie 'n behoorlike teoretiese begronding vir die opnames beskikbaar is nie. Gevolglik kan 'n ondersoeker die definisies van ingewikkelde konsepte nie vasstel nie. Dit ontlok operasionaliseringsvrae. Aspekte daarvan word 
in hierdie afdeling aangeraak. Die bespreking van die kwessies omtrent vraelyste se hantering geskied onder die volgende kategorieë in hierdie afdeling: dubbelloopbewoording, dubbelsinnige, onduidelike en algemene bewoording, abstrakte bewoording, emosioneelverwante bewoording, tydraamwerk vir vrae, leidende vrae en veronderstelde kennis.

\subsection{Dubbelloopbewoording}

Dubbelloopvrae kom voor waar die skakels "en" of "of" twee konsepte verbind wat eintlik onverwant is. Die respondent se antwoord kan dus na enige van die konsepte verwys. Drie voorbeelde lig hierdie leemte toe (in die verwysings na die Kerkspieël-opnames (KS) hieronder beteken EG Erediensgangersvraelys, GV Gemeentevraelys, LV Leierskapvraelys en PV Predikantevraelys):

- 'n Voorbeeld is: "Word jong leiers in die gemeente gebruik en toegerus?" (KS, 2010, GV, 3.6, 3.7, KS, 2014, GV, 3.6, 3.7). Hier is "gebruik" en "toegerus" verskillende konsepte. Sommige respondente se antwoorde kan dus gefokus wees op "gebruik", ander s'n op "toerus", en nog ander s'n op albei konsepte.

- Die vraag: "In watter mate beïnvloed die volgende samelewingsfaktore u bediening?" voorsien die kategorie: "Die feit dat mense in ons gemeente van mekaar oor geloof en geloofsuitlewing verskil, bemoeilik my bediening" (KS 2000, PV, 192). In hierdie kategorie kan respondente fokus op "geloof" en/of "geloofsuitlewing". 'n Verbinding van twee vervlegte konsepte, maak die kategorie net nog meer ingewikkeld.

- Onder die tema "Gemeentetipologie" verskyn die volgende teenoorgestelde stellings: "In ons gemeente is mense die fokus en bepaal dit die verhoudinge. In ons gemeente is die doel wat ons nastreef die fokus, en bepaal dit die verhoudinge" (KS 2000, PV, 201). Hier toon die stellings ook 'n dubbelslagtigheid. Dit gaan oor mense/ doel as fokus én mense/doel as bepalend vir verhoudings.

- Onder dieselfde tema kom 'n soortgelyke dubbelslagtigheid voor by die teenoorgestelde stellings: "Die verhoudinge tussen gemeentelede en die ampte (leraar, ouderlinge, ens.) is baie ontspanne en informeel. Die verhoudinge tussen gemeentelede en die ampte (leraar, 
ouderlinge, ens.) is baie styf en formeel" (KS 2000, PV, 202). Weereens is "die ampte" 'n te algemene begrip wat uiteenlopende kategorieë insluit soos leraar en ouderlinge. Die verhouding met ouderlinge of diakens kan ontspanne wees, maar nie noodwendig met die leraar nie. "Ontspanne" (sonder spanning) en "informeel" (sonder voorskrifte) het ook verskillende betekenisvelde wat die spesifiekheid van die vraag ondermyn.

Vanuit die voorbeelde hier bo is dit duidelik dat navorsers items van vrae noukeurig moet formuleer om eenduidige betekenis te verseker.

\subsection{Dubbelsinnige, onduidelike en algemene bewoording}

In die Kerkspieël-vraelyste kom vrae voor met dubbelsinnige, onduidelike en algemene bewoording. Dit hou verband met betekenisse wat nie helder uitgeklaar is nie. Hier word vyf voorbeelde verskaf:

- Dié voorbeeld is reeds gebruik: "Word jong leiers in die gemeente gebruik en toegerus?" (KS, 2006, GV, 3.6, 3.7, KS, 2010, GV, 3.6, 3.7, KS, 2014, GV, 3.6, 3.7), Hier is dit nie duidelik wat met die "gebruik" van jong leiers bedoel word nie. Dit fokus nie die respondent op 'n spesifieke betekenis nie.

- In die stelling, "Stem u saam of nie: Hierdie gemeente en predikant(e) pas in die algemeen goed by mekaar" (KS, 2006, LV, 38, KS, 2006, EG, 48, KS, 2010, EG, 24), is "pas bymekaar" oop vir vele interpretasies.

- By die vraag, "In die geval van 'n krisis in die plaaslike gemeenskap, het die gemeente 'n betekenisvolle rol om te speel?" (KS, 2014, GV, 8.5), is dit nie duidelik wat "krisis" en "betekenisvolle rol" beteken nie.

- In, "Word die naskoolse jongmense en jong volwassenes in u gemeente op 'n spesifieke wyse bedien?" (KS, 2010, GV, 3.8, KS, 2014, GV, 3.8), is dit nie duidelik wat "spesifieke wyse" behels nie. Die kategorie "naskoolse jongmens en jong volwassene" is ook nie omskryf nie.

- In, "In watter mate help die eredienste en aktiwiteite van hierdie gemeente u in u alledaagse lewe?" (KS, 2006, EG, 22, KS, 2010, EG, 6) is die betekenis van "alledaagse lewe" vaag. Respondente kan verskillende betekenisse daaraan gee. 
Hierdie voorbeelde toon dat bewoording respondente tot allerlei betekenisse kan prikkel terwyl meting juis spesifiekheid wil verseker.

\subsection{Abstrakte bewoording}

In abstrakte bewoording is die konsepte veels te algemeen aangewend. Opsigself mag hierdie konsepte se betekenis vanselfsprekend lyk, maar in die gesprekskonteks van 'n vraelys, is dit nie meer selfverklarend nie. Vier voorbeelde belig hierdie punt:

- In die vraag, "Hoe sou u u gemeente se verwagting ten opsigte van u rol omskryf en wat sou u eie voorkeur wees?" word die volgende kategorieë gelys wat elkeen vir unieke interpretasies oop is: " 1 'n Priester as leier wat die tradisie beskerm en die Here se genade bemiddel. 2 'n Prediker wat oral in alle omstandighede die Woord moet verkondig. 3 'n Toeruster wat die lidmate se gawes help ontwikkel sodat elkeen die gemeente en gemeenskap daarmee kan dien. 4 'n Profeet wat op sosiale, maatskaplike, ekonomiese en politieke gebied misstande onbevrees uitwys en die gemeenskap begelei om te verander" (KS 2000, VP, 10, KS 2004, VP, 9). Daar bestaan egter nie gemeenskaplike betekenisse vir die volgende konsepte nie: "priester", "tradisie", "genade", "alle omstandighede", "toeruster", "gawes”, “ontwikkel”, "misstande” en "verander”. As konsepte soos hierdie gebruik word, met ruimte vir uiteenlopende verstaan daarvan, raak die response betekenisloos omdat respondente die vrae nie konsekwent verstaan het nie.

- By die tema, "Rolverwagtinge, verhouding met gemeente", word die volgende teenstellende stellings gemaak: "Gee my ruimte vir vernuwing/inisiatief/kreatiwiteit. Verkies dat ek net by die tradisionele bediening en ordes hou" (KS 2000, PV, 20:209, KS 2004, PV, 19:173) Hierdie ophoping van abstrakte konsepte ("vernuwing/ inisiatief/kreatiwiteit", "tradisionele bediening en ordes") lei tot 'n meervoud betekenisse wat die betroubaarheid van metings ondermyn.

- 'n Ander vraag lui: "Hoe gereeld beleef u iets van die volgende tydens eredienste in die gemeente?" met kategorieë: "God se teenwoordigheid, Inspirasie, Verveling, Verwondering, Vreugde, Frustrasie, Spontaneïteit, Roepingsvervulling" (KS 2006, LV, 30, KS, 
2006, EG, 40, KS, 2010, EG, 40) is elkeen van die konsepte oop vir 'n unieke interpretasie want "beleef" is 'n ervaring eie aan elke mens.

- Die stelling, "Stem u saam of nie: "God word vir menslike sonde kwaad" (KS, 2010, EG, 49) veronderstel dat die respondente dieselfde beskouings deel oor wat "God", "sonde" en "kwaad" behels - sake wat nie veronderstel kan word nie.

Dit is belangrik dat konsepte selfverklarend is. Hoe algemener en niespesifiek die konsepte is, hoe sterker kan die respondente se vertolking daarvan verskil.

\subsection{Emosioneelverwante bewoording}

Wanneer navorsers emosioneelverwante konsepte in 'n vraelys gebruik, moet hulle in ag neem dat emosionaliteit nie gestandaardiseer by mense voorkom nie. By implikasie sal die meting daarvan dus ook nie akkuraat wees nie. Emosioneelverwante konsepte kom in die volgende voorbeelde voor.

- Tipiese gevalle lees: "Beoordeel asseblief elkeen van die volgende stellings so eerlik moontlik: Ek is baie gelukkig as predikant in die gemeente (KS 1996, PV 6:1, KS 2000, PV 5:51, KS 2004, PV 5:33). Ek beleef tans 'n laagtepunt in my geestelike lewe (KS 1996, PV 6:2, KS 2000, PV, 5:62, KS 2004, PV 5:35). Die gemeente verwag te veel van my (KS 1996, PV 6:3, KS 2000, PV, 5:63, KS 2004, PV, 5:36). Die bediening plaas my onder geweldige spanning (KS 1996, PV 6:5, KS 2000, PV, 5:62, KS 2004, PV, 5:37). Ek voel lus om die handdoek in te gooi (KS 1996, PV 7:2, KS 2000, PV, 5:67, KS 2004, PV, 5:38). Die aansprake van die gemeente op my vrou se dienste is te veeleisend (KS 1996, PV 7:1, KS 2000, PV, 5:66, KS 2004, PV, 5:39). Ek geniet my werk (KS 1996, PV 7:4, KS 2000, PV, 5:69, KS 2004, PV, 5:40). My gesondheid is bevredigend (KS 1996, PV 7:5, KS 2000, PV, 5:70, KS 2004, PV 5:41). Ek is eensaam in die bediening (KS 2004, PV, $5: 45$ ). Ek sukkel om aan te pas by 'n snelveranderende omgewing (KS 2004, PV, 5:46). Ek voel magteloos in 'n wêreld met al sy aansprake (KS 2004, PV, 5:47). Ek beleef spanning oor die eise wat lidmate aan my stel (KS 2004, PV, 5:48). Die gemeente is tevrede met my preke (KS 2000, PV 5:58). My kinders is negatief teenoor die NG 
Kerk (KS 2000, GV, 5:72). My huwelik is gelukkig (KS 2000, PV, 5:73). In hierdie items is verskeie konsepte oop vir uiteenlopende betekenisgewing. Dit geld konsepte soos: "gelukkig", "laagtepunt", "verwag", "geweldige spanning", "handdoek in te gooi", "aansprake", "geniet", "bevredigend", "eensaam", "aanpas", "magteloos", "tevrede” en "negatief".

- In die teenstellende stellings, "Verhoudinge in ons gemeente is opreg en warm. Verhoudinge in ons gemeente is koud en klinies." (KS 2000, PV, 19) is "opreg", "warm", "koud" en "klinies" ook nie konsepte wat op 'n spesifieke betekenis dui nie.

Emosioneelgelaaide konsepte word in semantiese differensiaalmetings gebruik, maar ontledings daarvan het aangetoon dat menslike emosies gekoppel is aan evaluering, vermoëns en handeling. Vrae wat evalueer, vermoëns ondersoek en handeling beoordeel, kan dus inligting bekom wat deur emosies versluier word.

\subsection{Tydsraamwerk in vrae}

Dit is belangrik dat respondente duidelik weet watter tydsraamwerk in 'n vraag veronderstel word. In die item, "Watter van die volgende beskryf die gemeente se finansiële posisie die beste?” (KS, 2006, GV, 4.5, KS, 2010, GV, 4.3 , KS, 2014, GV, 4.3) ontbreek die veronderstelde tydperk. Die tyd kan wees: op die oomblik (slegs in lopende rekening of bates ingesluit); soos dit in die vorige jaar se finansiële verslag aangedui is; of soos dit volgens die begroting verloop, ensovoorts.

\subsection{Leidende vrae}

Leidende vrae skep 'n spesifieke respons of veronderstel dat die respondent 'n bepaalde antwoord voorhou. Hier geld 'n vraag soos: "U mag van verskillende style van musiek hou, maar wat verkies u in die erediens?" (KS, 2006, LV, 21). Deur die vraag te antwoord, sal die respondent by implikasie erken hy/sy hou van verskillende style musiek, of dat mense van verskillende style van musiek mag hou. In werklikheid het die respondent dalk 'n ander mening hieroor, maar die vraag bied nie so 'n opsie nie. 


\subsection{Veronderstelde kennis}

Wanneer vrae gevra word, moet die inligting geredelik by die respondent beskikbaar wees. Indien nie, word die response geskep of geraai. Dit maak die inligting by implikasie verdag. Hier onder is voorbeelde van vrae waar die respondente nie noodwendig oor die nodige inligting beskik nie.

- Respondente sal moeilik 'n presiese antwoord kan gee op die vraag: "Watter persentasie Engelse liedere sing u Gemeente?" (KS 2000, GV, 2.4) Hierdie vraag is meer spesifiek gemaak in die 2004-opname: “Hoeveel Engelse liedere per diens?" (KS 2004, GV, 2.4) In 2006 is egter weer teruggekeer na die swakker geformuleerde vraag wat na persentasie vra (KS, 2006, GV, 2.5).

- 'n Moeilike bepaalbare vraag was: "Hoeveel lidmate in u gemeente is MIV-positief?" (KS 2004, GV, 9.1). Hierdie vraag is darem verbeter in 2006 met: "Hoeveel lidmate, waarvan u weet, in u gemeente is MIV-positief?" (KS, 2006, GV, 8.2). Dieselfde kom voor by die vraag: "Hoeveel lidmate in u Gemeente is terminaal siek weens VIGS?" (KS 2004, GV, 9.2). Dié vraag is ook in 2006 verbeter na: "Hoeveel lidmate, waarvan u weet, in u gemeente is terminaal siek weens VIGS?" (KS, 2006, GV, 8.2). Respondente sou dit waarskynlik moeilik gevind het om akkuraat inligting te gee oor: "Hoeveel getroude werklose mense woon in u Gemeente?" (KS 2000, GV, 10.3); of: "Hoeveel jongmense in u Gemeente wat skool verlaat het en/of pas afstudeer het, is werkloos?" (KS 2000, GV, 10.4). Vrae moet spesifiek en duidelik wees. In die laaste genoemde vraag is "jongmense" en "werkloos" (kry nie werk nie, wil nie werk nie, ongeskik vir werk) ongedefinieerd. Voorts is die tydstip/tydperk waarvoor die inligting gevra word, nie gestel nie.

- 'n Verdere vraag is: “Is daar 'n kleingroepbediening in u Gemeente? Indien ja, gee kortliks 'n beskrywing van die model wat $\mathrm{u}$ gebruik?” (KS 2000, GV, 6.3) In die Kerkspieël van 2000 is die volgende modelopsies genoem: "Ermelo-Oos/Ralph Neighbour, George/Gemeentevreugde, Tafelbaai, Morelettapark, Buvton, Wyksbyeenkomste/Bybelstudiegroepe/'n Eie model" (KS 2000, GV, 6.3). Kennis van wat hierdie modelopsies se betekenis is, kan nie bloot veronderstel word nie. Met die Kerkspieël vir 2004 is hierdie 
modelopsies uitgelaat en dit 'n oop vraag gemaak waarin 'n eie model beskryf kon word (KS 2004, GV, 6.10).

- Die volgende stelling se kategorieë is besonder vaag: “Tot watter mate stem u saam met of verskil u van die onderstaande stellings?" Die kategorieë lees: "Die Ned. Geref. Kerk - 1. Is gewillig om aan te pas by veranderde eise v/d tyd, 2 . Het 'n betekenisvolle impak op ons gemeenskap, 3. Dra by tot versoening in Suider-Afrika, 4 . Is verdraagsaam teenoor alle rassegroepe in SA, 5. Hou tred met veranderende tye, 6 . Diskrimineer nie op grond van geslag nie, 7. Is standvastig/gevestig in hul weë, 8. Is eksklusief, 9. Bevorder eenheid in die kerk, 10. Diskrimineer nie op grond van seksuele oriëntasie nie. 11. Is konserwatief, 12. Ondersteun transformasie in ons gemeenskap, 13. Is 'n plek waar verskillende groepe welkom voel, 14. Word gekniehalter deur sy verlede, 15. Bereik nog die jeug/jong volwassenes" (KS 2004, PV, 24).

- Die navorser kan nie bloot veronderstel dat respondente menings sal hê oor die Ned. Geref. Kerk se posisie omtrent die volgende sake nie: "veranderde eise van die tyd", "betekenisvolle impak", "versoening in Suider-Afrika", "verdraagsaam”, "hou tred”, “diskrimineer", "standvastig/gevestig”, "eksklusief”, "eenheid”, "konserwatief”, "transformasie", "welkom voel”, "gekniehalter" en "bereik". Met hierdie stelling en die kategorieë daarvan word veronderstel dat die respondente ingesteldhede oor al hierdie sake het. Dit is nie noodwendig die geval nie. Die stelling en meegaande kategorieë is gevolglik geneig om eerder response skep as om bestaande menings te meet.

Dit is uiters belangrik dat vrae wat aan respondente gestel word, toepaslik in hulle leefwêreld sal wees.

Hierdie afdeling het bepaalde kwessies by vraelyste uitgewys, soos reeds bespreek: van dubbelloopbewoording tot veronderstelde kennis. Daar is bevind dat hierdie kwessies die gehalte van die metings ondermyn. Gevolglik moet sulke kwessies ernstige aandag geniet wanneer vraelyste saamgestel word. 


\section{Gevolgtrekking}

Hierdie artikel redeneer dat praktiese teologie 'n belangrike interpreteerder van die kerk se funksionering is. Aangesien uitsprake oor teologiese sake en die voorhande werklikheid in vele gevalle vervleg lê, behoort teoloë ook empiriese benaderings kundig te gebruik om sulke kwessies te ondersoek. Opnames is 'n kernmiddel in empiriese ondersoeke. ' $n$ Goedbeplande samestelling van vraelyste is 'n uiters belangrike onderdeel van gehaltebeheer wanneer inligting ingesamel word. Die saamstel van vraelyste as sodanig hou egter reeds 'n uitdaging in. Dit rede is dat so 'n saamstelling inspeel op menslike kommunikasie en betekenisgewing wat vloeibaar en uniek is, maar poog om gestandaardiseerde en gekontroleerde response te ontlok. Gevolglik moet die gehalte van elke item in 'n vraelys ondersoek word.

As voorbeeld wys hierdie artikel uit hoe daar wel in die Kerkspieël-opnames van die Ned. Geref. Kerk vrae voorgekom het wat nie genoegsaam die tipiese kwessies gehanteer het nie - soos dit hier bo uitgewys is. Hierdie kwessies en moontlike regstellings kan in navorsing oor praktiese teologie as algemene voorbeelde dien. Dit dui aan waarvoor navorsers sensitief moet wees wanneer hulle vraelyste saamstel om sodoende gehalte-opnames in hierdie studieveld te verseker. Die artikel lewer dus 'n bydrae tot die versterking van empiriese navorsing in praktiese teologie.

\section{Bibliografie}

Babbie, E 2007. The Practice of Social Research. Belmont, CA: Thomson Wadsworth.

Bryman, A 2016. Social Research Methods. Oxford: Oxford University Press.

Das, A \& Laumann, EO 2010. How to get valid answers from survey questions: What we learned from asking about sexual behaviour and the measurement of sexuality. (In Walford, G, Tucker, E \& Viswanathan, M. The Sage handbook of measurement. London: Sage. p. 9-26.) 
De Vos, AS, Stydom, H, Fouché, CB \& Delport, CSL 2011. Research at grass roots for the social sciences and human service professions. Pretoria: Van Schaik Publishers.

Dreyer, JS 2012. Practical Theology and Intradisciplinary Diversity: A Response to Miller-McLemore's Five Misunderstandings about Practical Theology. International Journal of Practical Theology. 16(1): $34-54$.

Fuchs, O. Relationship between practical theology and empirical research. Journal of Empirical Theology, 14(2):5-19.

Hammersley, M 2010. Is social measurement possible, and is it necessary? (In Walford, G, Tucker, E \& Viswanathan, M. The Sage handbook of measurement. London: Sage. pp. 409-426.)

Heimbrock, H-G 2011. Practical theology as empirical theology. International Journal of Practical Theology, 14:153-170.

Heitink, G. Practical Theology. History. Theory. Action Domains. Cambridge: William B. Eerdmans Publishing House.

KS1981 sien Van Eeden, IJ, Coetzee, CH, Nel, M, Prins, JG \& Smuts jnr M. 1982.

KS1985 sien Van Eeden, IJ \& Smuts, M. 1986.

KS1989 sien Schoeman, WJ \& Smuts, M. 1989.

KS1993 sien Schoeman, WJ \& Bisschoff, JH 2004.

KS1996 sien Olivier, GC, Schoeman, WJ, Smuts, M \& Bisschoff, JH 1996.

KS2000 sien Schoeman, WJ \& Bisschoff, JH 2000.

KS2004 sien Schoeman, WJ \& Bisschoff, JH 2004.

KS2006 sien Schoeman, WJ \& Bisschoff, JH 2004.

KS2010 sien Schoeman, WJ \& Van der Merwe, W 2010.

KS2014 sien Schoeman, WJ 2014.

Nel, M \& Schoeman, WJ 2015. Empirical research and congregational analysis: Some methodological guidelines for the South African context. Acta Theologica, 22:85-102. 
Nipkow, KE, 1993. Empirical research within practical theology. Journal of Empirical Theology, 6(1):50-63.

Olivier, GC, Schoeman, WJ \& Smuts, M 1993. Kerkspieël IV. Pretoria: Ongepubliseerde verslag.

Olivier, GC, Schoeman, WJ, Smuts, M \& Bisschoff, JH 1996. Kerkspieël V. Pretoria: Ongepubliseerde verslag.

Oppenheim, AN 1968. Questionnaire design and attitude measurement. London: Heinemann.

Osmer, RR 2008. Practical Theology. An Introduction. Cambridge: William B. Eerdmans Publishing Company.

Pieterse, $\mathrm{H}$ The empirical approach in practical theology: A discussion with JA van der Ven. Religion \& Theology, 1(1):77-83.

Schoeman, WJ 2011. Kerkspieël - 'n kritiese bestekopname. Ned Geref Teologiese Tydskrif, 52(3-4):472-488.

Schoeman, WJ 2014. Kerkspieël 2014. Gemeentevraelys. Pretoria: Ongepubliseerde vraelys.

Schoeman, WJ \& Bisschoff, JH 2000. Kerkspieël 2000. Metodologiese verantwoording. Pretoria: Ongepubliseerde verslag.

Schoeman, WJ \& Bisschoff, JH 2004. Kerkspieël 2004. Metodologie. Pretoria: Ongepubliseerde verslag.

Schoeman, WJ \& Smuts, M 1989. Kerkspieël III. Pretoria: Ongepubliseerde verslag.

Schoeman, WJ \& Van der Merwe, W 2010. Kerkspieël 2010.

Gemeentevraelys en Erediensgangersvraelys. Pretoria:

Ongepubliseerde vraelyste.

Schwarz, N 2010. Measurement as cooperative communication: What research participants learn from questionnaires. (In Walford, G, Tucker, E \& Viswanathan, M The Sage handbook of measurement. London: Sage. pp. 43-59.) 
Tucker, E 2010. Towards a more rigorous scientific approach to social measurement: Considering a grounded indicator approach to developing measurement tools. (In Walford, G, Tucker, E \& Viswanathan, M. The Sage handbook of measurement. London: Sage. pp. 313-335)

Tucker, E, Viswanathan, M \& Walford, G 2010. Reflections on social measurement: How social scientists generate, modify, and validate indicators and scales. (In Walford, G, Tucker, E \& Viswanathan, M. The Sage handbook of measurement. London: Sage. pp. 1-5.)

Van der Ven, J 1993. Practical Theology: An Empirical Approach. Kampen: Kok Pharos Publishing House.

Van Eeden, IJ \& Smuts, M 1986. Kerkspieël II. Pretoria: NG Kerkboekhandel Tvl.

Van Eeden IJ, Coetzee, CH, Nel, M, Prins JG \& Smuts, jnr M. 1982. Kerkspieël. Pretoria: NG Kerkboekhandel Tvl.

Van Huyssteen, W 1987. Teologie as kritiese geloofsverantwoording. Pretoria: Raad vir Geesteswetenskaplike Navorsing.

Viswanathan, M 2010. Understanding the intangibles of measurement in the social sciences (In Walford, G, Tucker, E \& Viswanathan, M. The Sage handbook of measurement. London: Sage. pp. 285-311.)

Miller-McLemore, BJ 2012. Introduction. The Contributions of Practical Theology. (In Miller-McLemore, BJ 2012. The Wiley-Blackwell Companion to Practical Theology. West Sussex: Blackwell Publishing Limited. pp. 1-20.)

Miller-McLemore, BJ 2012. The Wiley-Blackwell Companion to Practical Theology. West Sussex: Blackwell Publishing Limited.

Zaaiman, SJ 2011. 'n Beoordeling van die metodologiese uitgangspunte van die Ned Geref Kerk se Kerkspieël-vraelyste. Ned Geref Teologiese Tydskrif, 52(3-4):655-683.

Zaaiman. SJ \& Rautenbach. EH 2011. 'n Vergelyking van die Ned Geref Kerk se Kerkspieël-vraelyste. Ned Geref Teologiese Tydskrif, 52(34):643-654. 